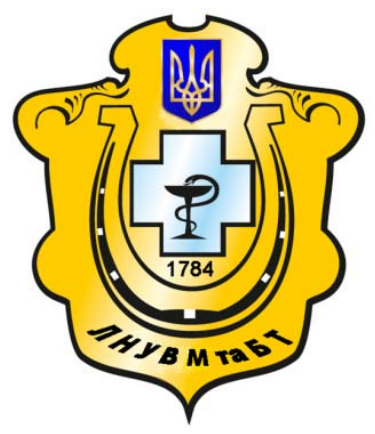

Науковий вісник Львівського національного університету ветеринарної медицини та біотехнологій імені С.3. Гжицького

Scientific Messenger of Lviv National University of Veterinary Medicine and Biotechnologies named after S.Z. Gzhytskyj

doi:10.15421/nvlvet6644

ISSN 2413-5550 print

ISSN 2518-1327 online

$\underline{\text { http://nvlvet.com.ua/ }}$

УДК 619:616.81:636.7

\title{
Патоморфологічні особливості лейдигоми собак
}

\author{
Н.І. Шестяєва, Я.В. Осадчук \\ shestiaieva_ni@nubip.edu.ua \\ Начіональний університет біоресурсів і природокористування Украӥни, \\ вул. Героїв Оборони, 11, м. Київ, 03041, Украӥна
}

\begin{abstract}
Проведені дослідження з вивчення частоти діагностування, морфологічних, клінічних та макроскопічних особливостей різних гістологічних типів новоутворень сім яників собак. Матеріал для досліджень був отриманий під час планових операцій з приводу видалення новоутворень сім'яників у собак в різних клініках ветеринарної медицини міста Києва. Пухлини були розподілені на пухлини строми статевого тяжу та герміногенні пухлини. Серед пухлин строми статевого тяжу реєстрували лейдигому та сертоліому. Описані макроскопічна та гістологічна характеристика лейдигоми у собак, яка становить 12,5\% від усіх новоутворень сім'яників. Середній вік собак із лейдигомою - 9 років, найбільшу частку займають собаки таких порід, як фокстер'єри та тойтер'єри. Лейдигома має дещо повільніший ріст в порівнянні з іншими пухлинами сім'яників, метастазів не відмічають. В половині випадків тварини не мали клінічних ознак. Більшість лейдигом супроводжуються патологією параанальних залоз. Новоутворення реєструють як на правому, так $і$ на лівому сім'яниках. Більшість пухлин правильної овальної форми, бурого або сірого кольору, різної консистенції та розміру без ознак виразок чи некрозу. Мікроскопічно пухлина складається із гландулочитів різного ступеня зрілості, які розташовані у вигляді тялсів, пучків, пластів. Спостерігають полігональні клітини з еозинофільною зернистою або вакуолізованою цитоплазмою, що містить ліпіди. Стома пухлини характеризується ділянками кальииффікації. Відмічають мітотичну активність. Дослідження із вивчення особливостей гістологічної будови окремих типів пухлин сім'яників дозволить оптимізувати гістологічну діагностику неоплазм.
\end{abstract}

Ключові слова: негерміногенні пухлини, пухлини строми статевого тяжу, доброякісні пухлини, лейдигома, новоутворення сім'яників, собаки.

\section{Патоморфологические особенности лейдигомы собак}

\author{
Н.И. Шестяева, Я.В. Осадчук \\ shestiaieva_ni@nubip.edu.ua
}

Национальный университет биоресурсов и природопользования Украинь,, ул. Героев Обороны, 11, Киев, 03041, Украина

\begin{abstract}
Проведены исследования по изучению частоты диагностирования, морфологических, клинических и макроскопических особенностей различных гистологических типов новообразований семенников собак. Материал для исследований был получен во время плановых операций по поводу удаления новообразований семенников у собак в различных клиниках ветеринарной медицины города Киева. Опухоли были разделены на опухоли стромы полового тяжа и герминогенные опухоли. Среди опухолей стромы полового тяжа регистрировали лейдигому и сертолиому. Описаны макроскопическая и гистологическая характеристика лейдигомы у собак, которая составляет 12,5\% от всех новообразований семенников. Средний возраст собак с лейдигомой - 9 лет, наибольшую долю занимают собаки таких пород, как фокстерьеры и тойтерьеры. Лейдигома имеет более медленный рост по сравнению с другими опухолями семенников, метастазов не отмечают. В половине случаев животные не имеют клинических признаков. Больиинство лейдигом сопровождаются патологией параанальных желез. Новообразования регистрируют как на правом, так и на левом семенниках. Большинство опухолей правильной овальной формы, бурого или серого ивета, разной консистенции и размера без признаков язв или некроза. Микроскопически опухоль состоит из гландулоцитов разной степени зрелости, которые расположены в виде тяжей, пучков, пластов. Находят
\end{abstract}

\section{Citation:}

Shestiaieva, N.I., Osadchuk, Y.V. (2016). Pathomorphological features of canine leydig cell tumor. Scientific Messenger LNUVMBT named after S.Z. Gzhytskyj, 18, 2(66), 217-219. 
полигональные клетки с эозинофильной зернистой или вакуолизированной иитоплазмой, которая содержст липиды. Строма опухоли характеризуется участками кальцификации. Отмечают митотическую активность. Исследования по изучению особенностей гистологического строения отдельных типов опухолей семенников позволит оптимизировать гистологическую диагностику неоплазм.

Ключевые слова: негерминогенные опухоли, опухоли стромы полового тяжа, доброкачественные опухоли, лейдигома, новообразования семенников, собаки.

\title{
Pathomorphological features of canine leydig cell tumor
}

\author{
N.I. Shestiaieva, Y.V. Osadchuk \\ shestiaieva_ni@nubip.edu.ua \\ National University of life and environmental sciences of Ukraine, \\ Heroyiv Oborony Str., 11, Kyiv, 03041, Ukraine
}

The research for the study of morphological, clinical and macroscopic characteristics of the different histological types of canine testicular tumors. Material was obtained during a routine surgery for the removal of testicular tumors in dogs in clinics of veterinary medicine in Kiev. Tumors were divided into sex-cord stromal tumors and germ cell tumors. Among the sex-cord stromal tumors recorded leydig (interstitial) and sertoli cell tumors. Macroscopical and histologic characteristics of canine interstitial (Leydig) cell tumor are described. It is $12.5 \%$ of all testicular tumors. The average age of dogs is 9 years. Largest share is breeds dog such as foxterriers and toyterriers. Interstitial (Leydig) cell tumor has a slower growth compared to other tumors the testicle, no metastases. Half the animals had no clinical signs. Most interstitial (Leydig) cell tumor go together with the pathology of adnexal structures. This is because Leydig cell tumor lead to increased levels of androgens. This fact may cause pathology of adnexal structures. Neoplasms are recorded both on the right and the left testis. Leydig cell tumor was not related to the cryptorchid testicles. Most tumors regular oval, brown or gray color, different texture and size with no signs of necrosis or ulceration. The average volume of tumors ranged from 2 to $20 \mathrm{~cm}^{2}$. Microscopically, the tumor is composed of cells that resemble Leydig cells and that are arranged into islands or tubular structures. Find polygonal eosinophilic cells with granular or vacuolated, which contains lipids. Nuclei were round mesh of chromatin and distinct nucleolus. Sometimes noted the large cells with 1, 2 or more nucleoli. In some cases, found elongated fusiform cells with small nuclei and granular eosinophilic cytoplasm. Tumor stroma characterized by calcification. Note mitotically active cells. Cysts lined by tumor cells are present in some tumors. Distinction between benign and malignant forms on purely histological criteria, in the absence of metastasis, often is difficult. Studies on the features of histological structure of testicular tumors will optimize the histological diagnosis of neoplasms.

Key words: sex-cord stromal tumors, interstitial cell tumor, Leydig cell tumor, benign tumor, tumors of the testicle, dogs.

\section{Вступ}

Останнім часом лікарі ветеринарної медицини почали приділяти увагу вивченню різних факторів ризику, механізмів патогенезу новоутворень, морфологічних особливостей та значення різних прогностичних факторів. Це обумовлено значним ростом онкологічної патології у дрібних тварин та необхідністю розробки превентивних та терапевтичних заходів (McEntee, 1990). Проте у літературі недостатньо висвітлені питання про частоту виникнення новоутворень собак, фактори анамнезу, а також щодо особливостей мікроі макрохарактеристик новоутворень, 3 якими стикається лікар ветеринарної медицини.

Тестикулярні пухлини у кабелів зустрічаються часто (5 - 15\% від усіх новоутворень) та майже завжди є причиною втрати репродуктивної функції або і загибелі тварини (Shestiaieva, 2010). Вивчення саме патоморфологічних особливостей новоутворень сім яників є вкрай важливим для визначення точного діагнозу. Нажаль в Україні не проводяться систематичні патоморфологічні та епізоотологічні дослідження злоякісних пухлин у собак.

Метою роботи було вивчення частоти діагностування, морфологічні, клінічні та макроскопічні особливості різних гістологічних типів новоутворень сім яників собак. Згідно мети планувалось дослідити: патоморфологічні особливості різних гістологічних типів, їх клінічну картину та залежність між виник- ненням новоутворень сім `ників та анамнестичними даними.

\section{Матеріал і методи досліджень}

Матеріал для досліджень був отриманий під час планових операцій з приводу видалення новоутворень сім'яників у собак в різних клініках ветеринарної медицини міста Києва. Обробку патологічного матеріалу виконували за загальноприйнятими гістологічними методами.

\section{Результати та їх обговорення}

За принципами, що покладені в основу класифікації новоутворень сім'яників собак (Misdorp, 2002), пухлини, які трапилися у дослідженій випадковій вибірці, були розподілені на пухлини строми статевого тяжу та герміногенні пухлини. Серед пухлин строми статевого тяжу в наших дослідженнях реєстрували лейдигому та сертоліому.

Лейдигома - новоутворення сім'яників, яке походить 3 ендокриноцитів, що розташовані між прошаркам сполучної тканини за межами звивистих сім'яних канальців (клітини Лейдіга) (Gelberg and McEntee, 1987). Лейдигоми складали $12,5 \%$ від усіх новоутворень сім'яників та займали трете місце після семіноми та сертоліоми. На момент звернення до клініки середній вік собак склав 9 років. Всі тварини, в яких було діагностовано лейдигому були породистими. Найбільшу частку склали собаки таких порід, як фокс- 
тер'єри та тойтер'єри. Новоутворення діагностували як на правому, так і на лівому сім'яниках, жоден випадок лейдигоми не був пов'язан із сім'яниками, що не опустилися. В значній кількості пухлини були представлені поодинокими новоутвореннями, але реєстрували випадок, коли ураження мало вигляд декількох вузлів на одному сім'янику. Більшість пухлин собак мали правильну овальну форму, бурий або сірий колір і були пухкої та, іноді, щільної консистенції без ознак виразок чи некрозу. Розміри лейдигом собак дослідженої вибірки дуже варіювали. Середній об'єм новоутворень склав від 2 до $20 \mathrm{~cm}^{2}$. Тривалість захворювання, який визначався як час від появи клінічних ознак до моменту звернення в клініку, в середньому для лейдигом склала 8 місяців. Це був найвищий показник серед інших гістологічних типів новоутворень сім'яників, що може свідчити про дещо повільніший ріст лейдигом в порівнянні 3 іншими пухлинами сім'яників.

Половина тварин не мали суттєвих клінічних ознак, крім збільшеного ураженого сім'яника. В інших випадках новоутворення сім'яників супроводжувалось запаленням параанальних залоз. 3 літератури відомо, що більшість лейдигом призводять до підвищення рівня андрогенів, саме цей факт може стати причиною виникнення патології параанальних залоз. Жодного випадку лейдигоми сім'яника із наявністю метастатичних уражень нами відмічено не було.

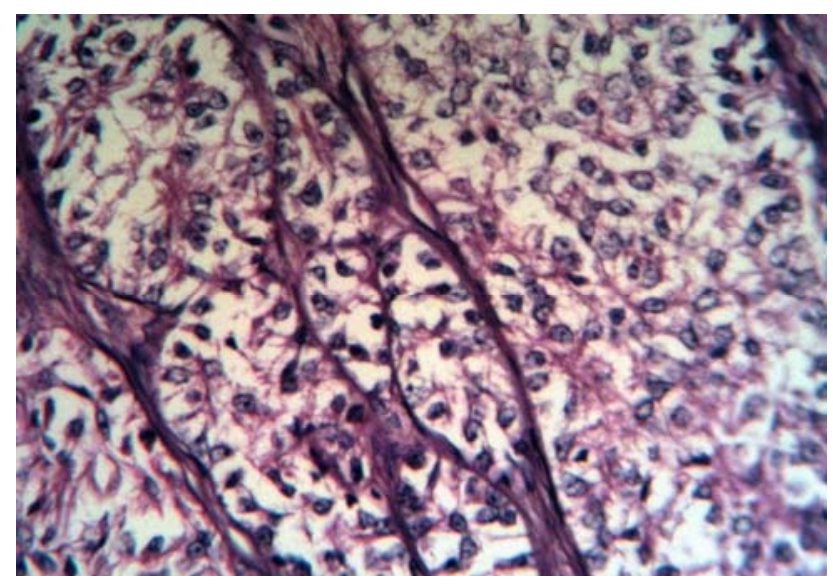

Рис. Клітини із світлою цитоплазмою та світлими ядрами із 1-2 ядерцями.

Фарбування гематоксиліном та еозином. Х 200

Мікроскопічно лейдигома складалась із гландулоцитів різного ступеня зрілості, що росли у вигляді тяжів, пучків, пластів. Переважно спостерігали полігональні, іноді шестигранні клітини з рясною еозино- фільною зернистою або вакуолізованою цитоплазмою, що містить значну кількість ліпідів (рис.). Ядра були круглі із сітчастим хроматином та вираженими ядерцями. Іноді відмічали великі клітини 3 1, 2 або декількома ядерцями. В деяких випадках знаходили витягнуті веретеноподібні клітини із невеликими ядрами та еозинофільною зернистою цитоплазмою. Відмічали виражений плеоморфізм клітин та мітотичну активність. Стома характеризувалась ділянками кальцифікації.

\section{Висновки}

Отже, лейдигома - доброякісна пухлина, яка складається із гландулоцитів різного ступеня зрілості та, завдяки своїм клінічним характеристикам, легко виявляється при зовнішньому огляді і пальпації мошонки, вона не дає метастазів та повільно росте. Зазвичай пухлина розвивається в одному сім'янику, що опустився і виробляє чоловічі статеві гормони (андрогени), підвищений рівень яких в організмі створює постійний фон, що сприяє виникненню патології пераанальних залоз.

Перспективи подальших досліджень. Визначення особливостей гістологічної будови окремих типів пухлин сім'яників, у т.ч. лейдигоми, дозволить оптимізувати та полегшити гістологічну діагностику неоплазм. Наразі визначення гістологічних типів новоутворень ускладнене використанням лікарями різних критеріїв та класифікацій. Тому дослідження патоморфологічних особливостей різних гістологічних типів пухлин тварин буде продовжено і надалі.

\section{Бібліографічні посилання}

Shestiaieva, N.I. (2010). Patomorfologichna harakteristika seminomi sobaki. Naukovi pratsi Pivdennogo filialu NUBIP Ukraini «Krimskiy agrotehnologichniy universitet»: Veterinarni nauki. Simferopol. 129, 250253 (in Ukrainian).

Gelberg, H.B., McEntee, K. (1987). Equine testicular interstitial cell tumors. Vet Pathol. 24, 231-234.

McEntee, K. (1990). Scrotum, spermatic cord, and testis: Proliferative lesions. Reproductive Pathology of Domestic Animals - Academic Press Inc., San Diego, 279-306.

Misdorp, W. (2002). Tumors of the genital systems. Tumor in domestic animals. Iowa State Press, 2002, 4, $575-612$.

Стаття надійшла до редакції 19.09.2016 